\title{
Legal regulation of the obligations old romanian law, grece and roman
}

\author{
Ion Țuţuianu PHd, "Vasile Alecsandri” University of Bacău, Romania
}

\begin{abstract}
Legal history shows that those who are defined obligation Romans definition valid today as a relationship as we submit to a benefit from a third party. Their importance lies in the fact that although rooted in ancient as it spread in all legal systems, across time and still keeping the same legal and economic importance.
\end{abstract}

\section{Keyword:}

obligation, law, contract, economic

The law appears as a necessity to regulate legal relations. Because some legal relations between the parties creates responsibilities, specific term used is that of obligation ${ }^{1}$

Starting from its etyomology Latin meaning "to bind" must show that the legal bond between two people, under which a person is entitled to claim from the other side, to execute a particular benefit.

Obligations, is an independent group of legal rules governing property relations homogeneous and non-property related personnel in the field of economic circuit, relationships that are established in the commercial circulation of material goods accompanying indirect transfer of material from one person to another. Obligations may be regarded as the legal form of economic circuit, ie-formula as the dynamics of economic relations.

In Romanian law, the first legal works as: Calimach Code in Moldova, in Annex to the order competition creditors (art. 1974-2012) established how credit recovery and the the Court designated as a residence debitor. (art. 1978)

To avoid excessive delay abuses art. 1987, provided that the periods do not exceed one year, and against subjective preferences, the user can determine the order of recovery by preemption.

he Romanian Country, The Rule of Caragea, regulates the obligations in Part III, which contains legal norms: for bargaining, selling, exchanging, renting or leasing, loan, interest, and art. 34-42, dealing with defects and eviction.

Greek law, there are two sources of obligations: contracts and delicts. If the Homeric ${ }^{2}$ period, law of obligations is characterized by a specific formalism primitive peoples, uttered a series of solemn words later consent to result in a document setting out the precise content of the contract. It is known that by 594 i.Hr., before Solon $^{3}$, the debtor was enslaved by legislation only required the debtor to the creditor was.

\footnotetext{
${ }^{1}$ Noțiunea de obligație are mai multe sensuri: datoria debitorului, titlu de valoare, înscris constatator, datorii morale.

${ }^{2}$ In aceasta perioada(1200i.Hr.-800i.Hr.. Homer , pentru greci reprezenta suma științei și a înțelepciunii iar textele sale aveau o autoritate absolută în toate domeniile.Homer a dat grecilor conștiința unității lor de neam și de cultură

${ }^{3} 3$ Om de stat atenian, legislator ( 640-560 î.H.) considerat printre cei șapte înțelepți ai Greciei antice,. Reformele sale pun bazele democrații ateniene și realizează un nou cod
} 
Among the possibilities creditor to secure payment of the debt, Greek law practice meet deposit as the amount of money that some other party attaches insurance if you would deny the other side of the contract

Another means of ensuring the rights of the creditor, the surety. This we find two forms: personal pledge, which was that a third person intervenes between the contracting parties and debtor that if the debtor does not pay at maturity, will pay it for him. and second, the real pledge, which consists in giving a receipt to the lender by the borrower for the latter to sell in case the first does not pay at maturity.

Another specific Greek form of creditor insurance, and showing a great development of law and legal thought, we find: mortgage $\mathbf{4}^{4}$-characterized by a debtor giving the best guarantee of a particular creditor fails to heritage property which the creditor but maturity creditor may sell the mortgaged property to recover damages.

How mortgage spread very quickly on Greek territory, as evidenced by the note that delimited the border terminals and properties that could be seen across the country

Besades lending buum, the mortgage proved its superiority over other forms of creditor insurance, given that the debtor remains mortgaged working, caring for it as any master of his work while being guaranteed at maturity and creditor rights may sell the property or otherwise use it.

Meet the existence of Greek law and the contract of sale, as being essential elements: seller, buyer, price if the sale was without formalities, making just by consent of the parties, transfer of ownership to take place when the buyer payment by the buyer price

Highlights conclusion is that all risks of loss or damage to work through, natural disasters, returning buyer, even if not yet paid the price

Another very common use contract with Greek law is the rental. This frequency is due to the many existing foreign citizens in Athens were deprived of political rights could not acquire property ${ }^{5}$ only way to live was renting. The lease was provided with various clauses duration, price, termination. Even when provided for in the contract, will not be sold during the rental dwelling and the owner sold them circumvention clause, the tenant can make use of what is called "dike blades" 6 to recover damages.

A form of land lease rental was that made money or goods but in many cases the tenant gave the owner a share of the harvest, but also hire labor, the small peasants could not face the competition of large owners or creditors and sold their labor in Athens ${ }^{7}$

For the execution of the channels, temples, roads, works contract was used. In this category falls the contract by which one undertakes to train a slave in Athens since there were many slaves who lacked any qualification.

Development of trade with the Greeks led to amplify certain financial transactions, for example: credit, monetary circulation.

In VI century i..Hr., the city-state in ancient Greece and temples began to issue its own coins. Because each city-state had its own currency, it was necessary to change one currency with another, which can be considered the first foreign exchange.

During this period the priests offered farmers loans and some people specialized in trade with money, offering the same services to other social categories. While these lenders, known as the keystone, began charging interest.

legislativ, intitulat -Constituția lui Solon. Vezi și Fustel de Coulanges,, Cetatea antică, vol.2, Editura meridiane, bucuresti, 1984, p.108

${ }_{5}^{4}$ Din fr. hypothèque

${ }^{5}$ Această categorie este cunoscută în Grecia antică sub numele de meteci. De la cuvântul metoikos, meta $=$ după și oikos locuință.

${ }^{6}$ Procedeu de adresare către organelle de judecată care s-ar traduce :justețea legii.Vezi și Aristotel, Etica Nicomahică, Editura Științifică și Enciclopedică, București, 1988., p. 123.

${ }^{7}$ Andrei Smochină, Istoria universală a statului și dreptului, Chişinău, 2002, p. 67 
Development of trade that were more sea trade is linked to a number of risks and this makes the interest is very high, sometimes up to $30 \%$, creating discontent among the population.

Therefore some Greek cities decided to create public banks named the trapeza.

These institutions were run and controlled by public officials, based on rules that can be associated first state regulation on banking activity.

Also increased trade and monetary circulation, leading to the development of various banking transactions, such as bank deposit, consisting of deposit with a bank or moneylender of money that the bank or moneylender concerned must repay on demand.

Often, however, there is some sort of account between the bank and the citizen, within which citizens make money repeatedly, the bank also raised several times, ending balance at the end only when the debtor and determine who is who is the creditor.

Greeks developed new contract is a contract company that requires association between two or more persons, with a view to profit, each participating capital, some with goods, others with physical work

Association Agreement stipulates sometimes the regulation of income and bearing damage, generally settling responsibilities in relation to benefits.

In addition we recognize contracts set into Greek law and contract term and even scarcity of resources has led experts to be retained, we can not omit the proof oratotului Demosthenes which a plea has been stated that his departure from Sicily Nicostel empowered to supervise and manage the business, responding to damage what they could entail the execution, showing the constituent assembly, not free as in the Roman world ${ }^{8}$

Research conducted throughout history reveal that the workshops in northern Italy ${ }^{9}$, produced a great deal of common property in the Roman world and beyond.

Closely coupled with the production of goods, the institution has an obligation paramount importance in Roman law, which is characterized by a subtle development of all essential legal reports of simple possession of goods, buyers and sellers, lenders and borrowers, contracts, bonds.

Regulated at a higher level, in terms of legal form and technique, bond Roman had great importance for the economic circuit of Rome, to strengthen the exploitation of slaves and free sărăcimii, reaching their maximum development during the first centuries of the Roman Empire, when production goods and commercial transactions peaked.

As an institution of law, an obligation arises with private property and social classes.

Romans claimed that a bond is born either a contract or a misdemeanor.

Satisfactorily solving practical problems, which required social life in old age, the bonds were not for lawyers particular theoretical concern, but as soon as the production of goods, slavery and trade developed, lawyers were forced to devote material obligations whose importance grew inevitably humor further studies..

As Greek law, Roman contracts are characterized by a rigorous formalism.

Most times it was enough to utter certain words solemn, to consider closed.

The same procedure applies to verbal contract called stipulation. Stipulations begins with a question and answer and the person to be stipulated (creditor) asks the debtor's future (promise) that promises to perform a certain benefit. Stipulation may concern not only money but also something. The rule imposes no one can stipulate to another and that was happening was null and void.

But so-called literal contract shall be entered in the trade register with the consent of the debtor, you will register each family pater which passed its household income and expenditure.

\footnotetext{
${ }^{8}$ Diana Dănișor, Considerații privind contractul de mandat, accepțiuni și evoluții ale termenului de drept, în Revista de Științe juridice, p. 217.

${ }^{9}$ Hadrian Daicoviciu, Dacia de la Burebista la cucerirea romană, Editura dacia, Cluj, 1972,p.98
} 
The higher trade agreements appear real and consensual. The real - acquired legally by submitting work and return work submitted

Of actual contracts known mutuum, fiduciary deposit, commodate the pledge

Mutuum-loan is a personal chattels to be consumed by the debtor and the creditor will be repaid in kind and quantity, as a loan of corn, wine, or money, to be used or consumed, and must be replaced with other corn, wine, or money.

Fiducia - is legal operation whereby one or more constitutive transferring real rights, rights instruments, securities or other property rights or a set of such rights, present and future, to one or more trustees they perform with a specific purpose, the benefit of one or more beneficiaries.

Comodatuum-is a contract whereby one party, called convenience, transmit and free temporary use of another party, called comodatar a good determined that the latter obligation to return it in its individuality, lender

Deposit-is contract whereby a person named depositor, provides storage to another person, called depozidat a duty thing, but its part, the return of the application.

Pledge a borrower submits his creditor in order to guarantee a claim possession of something. Working movable or immovable, which are subject to collateral will be retained by the lender to pay debt.

Consensual contracts are terminated by agreement of the parties simply

The most common contract in this category was the sale, whereby the seller is obliged to send the buyer, peaceful and lasting possession of something in exchange for a sum of money, called the price.

How the property was only for the rich, it is common lease contract whereby a person undertakes to procure another person to its temporary use of a thing or its services, or to perform a particular job, in exchange for money, called merses.

Trade development was done especially in companies that were the result of agreement between two or more persons who are obliged to put something together to achieve a profit

An example is provided by the tablets found in Rosia Montana, mentioning two contracts of society, which proves that this form of association was widespread throughout the Roman Empire, Being outlined legal personality and characteristic elements by forming a capital. ${ }^{10}$

One of them is a company to borrow money ended March 28, year 167, for a period of 16 months. Being a company usury is an indication that the trade was in full bloom

And exchange contract was widespread, being held in maximum Latin, I give you for give me. ${ }^{11}$ I'll give you a slave to paint me a picture or a slave emancipation to give me another one in his place and build a stove you to do me a fence

Also in Roman law, are obligations of offenses, ie facts prejudicial to the slave masters classsanctioned civil or praetorian. Public and private classification was made according to the interests that were violated specific or general.

And sanctions take this into account so that while the private fined paid by delinquent victim, the public, were sentenced to death or exile.

As mentioned civil law offenses: theft, intentional enrichment at the expense of another; damage, defined as damage caused willfully or negligently.

In 286 î.Hr., was settled that a person wrongfully killed a slave or an animal herd owner had to pay a fine calculated on the highest value on the slave or animal they had in previous offense, insult, offend intentionally made as a free people by words or deeds, and to be subject to a fine of $25 \mathrm{aşi}^{12}$

\footnotetext{
${ }^{10}$ Nicoleta Rodica Dominte, organizarea și funcționarea societăților comerciale, Editura C.H.Beck, București, 2008.

${ }^{11}$ Do ut des.

${ }^{12}$ Monedă romană de aramă sau de bronz, folosită ca unitate monetară
} 
Between offenses law praetorian mentioned: cunning, deception, whose sanction was made by praetor $^{13}$; metus, that produced fear of violence, which causes a person to enter into a legal disadvantage them; alienation by the debtor of his own heritage goods at the expense of creditors. In general, Roman law stated that a person who has been enriched at the expense of another is required to repay the amount wrongfully acquired.

\section{Bibliography}

1. Andrei Smochină, Istoria universală a statului și dreptului, , Chișinău, 2002

2. Robert Zipf, Piața obligațiilor, Editura HREMA , București, 2000

3. Istoria Dreptului Românesc, Editura Academiei, București, 1984

4. Elena Aramă, Istoria dreptului românesc, Chișinău,1997.

5. Hatmanu Ioan, Istoria doctrinelor juridice, Editura Fundației România de Mâine, București, 1994.

6. Drimba Ovidiu, Istoria culturii și civilizației, , București, 1990.

7. Molcuț Emil, Drept roman, București, 1997.

8. Diaconu C., Simion M., Istoria statului și dreptului, Craiova, 1999.

9. Hadrian Daicoviciu, Dacia de la Burebista la cucerirea romană, Cluj, 1972.

10. Nicoleta Rodica Dominte, Organizarea și funcționarea societăților comerciale, București, 2008.

${ }^{13}$ Pretor-titlu în Roma antică încă din anul 365 î.Hr. al conducătorului de armată, care avea şi atribuții de judecător 